PRZEGLĄD NAUK HISTORYCZNYCH 2017, R. XVI, NR 2

http://dx.doi.org/10.18778/1644-857X.16.02.10

ZBigniew ANusiK

UNIWERSYTET ŁÓDZKI

\title{
Kim była hrabianka Dorota von Helfenstein? Przyczynek do genealogii rodzin Kurzbachów i Helfensteinów w XV wieku
}

B ohaterka szkicu jest Dorota hr. von Helfenstein, żona Zygmunta von Kurzbacha, pierwszego barona na Żmigrodzie i Miliczu. Jest to postać niemal zupełnie nieznana, a historykom do chwili obecnej nie udało się ustalić jej pochodzenia. Co jednak wydaje się równie ciekawe, niewiele wiadomo także o rodzinie jej męża. Zanim przejdziemy zatem do wyjaśnienia zagadki pochodzenia hrabianki Doroty, wypada poświęcić słów kilka jej bardziej znanemu małżonkowi.

W literaturze historycznej brakuje jakichkolwiek wiadomości o rodzicach i młodości Zygmunta. Wiadomo jedynie, że był on zaufanym dworzaninem i doradca króla Czech (od 1471 r.) Władysława II Jagiellończyka. Na dworze praskim zrobił oszałamiająca wręcz karierę. Momentem przełomowym w życiu Zygmunta okazały się wydarzenia, które rozegrały się w latach 1489-1492. Konrad X Biały, ostatni książę oleśnicki $z$ dynastii Piastów, popadł w otwarty konflikt $z$ Maciejem Korwinem, królem Węgier oraz władca Moraw, Łużyc i Śląska. Latem 1489 r. wojska węgierskie opanowały księstwo, usunęły z Oleśnicy (Olsen) Konrada i zmusiły stany do złożenia holdu Maciejowi. Odsuniętemu od władzy Konradowi przekazano na rezydencję zamek Uraz i przyznano mu roczną pensję w wysokości 1600 guldenów. W tym samym roku Maciej Korwin wydzielił z księstwa oleśnickiego (pierwsze na Ślassku) wolne państwo stanowe

* Wydział Filozoficzno-Historyczny, Instytut Historii, Katedra Historii Nowożytnej, e-mail: zanusik@uni.lodz.pl. 
Syców (Wartenberg), które przekazał we władanie jednemu ze swoich stronników - Johannowi von Haugwitzowi ${ }^{1}$. Po rychłej śmierci Macieja Korwina, który zmarł 6 kwietnia 1490 r. w Wiedniu, Konrad X wrócił do Oleśnicy i rozpoczał pertraktacje o przekazanie swoich praw dziedzicznych do księstwa Piastom legnickim. Plany te nie zyskały jednak aprobaty nowego władcy Śląska - Władysława Jagiellończyka, który po śmierci Macieja zasiadł na tronie węgierskim. Władysław już w lutym 1491 r. (na mocy ugody zawartej w toku walki o koronę węgierska) przyrzekł bowiem przekazać znaczna część Śląska wraz $z$ dziedzictwem oleśnickim swojemu młodszemu bratu, Janowi Olbrachtowi. Ponieważ jednak ten ostatni zerwał zawartą ugodę i wznowił zakończoną w ostatecznym rozrachunku niepowodzeniem walkę o tron węgierski, sprawa przekazania mu księstwa oleśnickiego ostatecznie upadła. Kiedy więc 21 września 1492 r. zmarł bezpotomnie Konrad X Biały, król Władysław postanowił inaczej rozstrzygnąc sprawę dziedzictwa po nim. Jeszcze w 1492 r. z części terytorium księstwa oleśnickiego wykrojono wolne państwo stanowe Żmigród (Trachenberg), którego władca został zaufany dworzanin królewski Zygmunt von Kurzbach. W 1494 r. Władysław Jagiellończyk rozszerzył władztwo Zygmunta na inna część księstwa oleśnickiego, czyli utworzone właśnie wówczas wolne państwo stanowe Milicz (Militsch). W 1494 r. zatem we władaniu Zygmunta Kurzbacha znalazła się cała, graniczacca $z$ Polska, północna część dawnego księstwa oleśnickiego z Miliczem, Żmigrodem, Sułowem (Sulau), Prusicami (Prausnitz), Ciszkowem (Freyhan) i Nowym Zamkiem (Neuschloss). Kurzbach okazał się bardzo dobrym gospodarzem, podnoszacc $z$ upadku zniszczone w dobie wojen husyckich i późniejszych niepokojów na Ślassku dobra milicko-żmigrodzkie. W 1512 r. powiększył swoje śląskie posiadłości, kupując od węgierskiego magnata, hrabiego Jana Turza dobra Wińsko (Winzig), Wąsosz (Herrnstadt) i Ryczeń (Rützen). Ciesząc się niezmiennie zaufaniem króla Władysława, otrzymał nominację na komendanta Budy (Ofen), gdzie zmarł 27 listopada 1513 r. Zgodnie $z$ wyrażonym przed śmiercią życzeniem, został pochowany w odnowionym przez siebie kościele w Prusicach ${ }^{2}$.

\footnotetext{
${ }^{1}$ Por. K.G. Hoffman, Geschichte der Schleisen aus den ältesten Zeit bis aus unsere Tage, Bd. II, Schweidniz 1828, s. 464; F.G.G. Kurts, Denkwürdigkeiten aus der Geschichte der Stadt und Standesherrschaft Wartenberg, Wartenberg 1846, s. 24; R. Heck, Konrad X, [w:] Polski słownik biograficzny [dalej: PSB], t. XIII, Wrocław-Warszawa-Kraków 1967-1968, s. 595.

${ }^{2}$ Por. J. Sin a pius, Schleisischer Curiositäten Erste Vorstellung, Darinnen die ansehnilchen Geschlechter Des Schleisischen Adels, Mit Erzehlung Des Ursprungs,
} 
Historycy niemieccy jednogłośnie twierdzą, że $z$ małżeństwa $z$ Dorota hrabianka von Helfenstein Zygmunt pozostawił trójkę dzieci - synów Jana (Johanna) i Henryka (Heinricha) oraz córkę Annę. Warto może przytoczyć podstawowe informacje na ich temat. W $1514 \mathrm{r}$. Władysław Jagiellończyk potwierdził obu synom Zygmunta nadania poczynione na rzecz ich ojca. Początkowo bracia wspólnie rządzili państwem milicko-żmigrodzkim. W 1521 r. dokonali jednak, za zgodą króla Ludwika Jagiellończyka, podziału majątku po ojcu. Jan objął w posiadanie Milicz, Sułów, Cieszków i Nowy Zamek, a Henryk otrzymał Żmigród z Prusicami. Starszy z braci - Jan (Johann) żenił się trzykrotnie. Pierwszą jego żona, poślubiona w 1512 r., czyli jeszcze za życia ojca, była Salomea ks. żagańska (1475/76-1514), córka Jana II Szalonego (zm. 1504), ostatniego piastowskiego księcia na Żaganiu (Sagan) i Głogowie (Glogau) oraz Katarzyny ks. opawskiej, wdowa po zmarłym 12 lipca 1511 r. Albrechcie ks. ziębickim (von Münsterberg) i oleśnickim (von Olsen). Druga żoną Jana została Krystyna von Menhold. Obie wspomniane tu małżonki Jana zmarły jednak bezpotomnie. Dopiero z trzeciej żony - Anny Zborowskiej herbu Jastrzębiec, córki Marcina (zm. 1565), z czasem kasztelana krakowskiego, i Anny z Góry Konarskiej herbu Awdaniec doczekał się on syna Zygmunta II (1547-1579) oraz być może córki Anny. Jan (Johann) von Kurzbach, baron na Miliczu, zmarł 18 maja 1549 r. Wdowa po nim - Anna ze Zborowskich przed 1554 r. wyszła po raz drugi za mąż, poślubiając wielkopolskiego szlachcica Jana Borka Gostyńskiego herbu Gryzima. Drugi z braci - Henryk (Heinrich) von Kurzbach, baron na Żmigrodzie poślubił Annę von

der Wappen, Genealogien, der qualificirtesten Cavaliere, der Stamm-Häuser und Güter beschrieben..., Leipzig 1720, s. 202-203; Codex Germaniae Diplomaticus, worinnen Viele wortrefliche und zum Theil noch niemahls Borheins genommene..., Frankfurt und Leipzig 1733, s. 446-448 (nadanie Zygmuntowi Kurzbachowi, baronowi na Trachenbergu, zamku Milicz z przyległościami, datowane na 30 XI 1494 r.); J.C. Is el in, Neu-vermehrtes Historisch- und Geographisches Allgemeines Lexicon, Bd. III, Basel 1745, s. 61; N. Po1, Jahrbücher der Stadt Breslau, Bd. II, Breslau 1815, s. 199; L.A. Ge bh ard, Geschichte aller Wendisch-Slavischen Staaten, Bd. III, Basel 1797, s. 340; K.A. Mü1le r, Vaterländische Bilder, in eine Geschichte und Beschreibung den alte Burgfesten und Ritterschlösser Preussens, Glogau 1837, s. 200-201; O.L. G o e d s c h e, Geschichte und Statistik des Militsch-Trachenberg Kreises, Militsch-Breslau 1847; R. H e ck, op. cit., s. 595; J. G a r b a ci k, Jan I Olbracht, [w:] PSB, t. X, Wrocław-Warszawa-Kraków 1962-1964, s. 406. Nie znamy rzecz jasna daty urodzenia Zygmunta, ale należy przypuszczać, że przyszedł on na świat nie wcześniej niż w 1450 i nie później niż w 1455 r. Dodajmy również w tym miejscu, że w 1495 r. Władysław II Jagiellończyk pozostała część księstwa oleśnickiego wraz z Wołowem przekazał we władanie księciu ziębickiemu Henrykowi, który w zamian oddał królowi rodowe Podiebrady. 
Ilburg (Elenburg) z czeskiej gałęzi tego rodu, córkę Wilhelma von Ilburg-Ronov (zm. 1538), gubernatora Górnych Łużyc oraz Agnieszki von Helfenstein-Wisensteig, dalekiej kuzynki swojej matki. $Z$ tego małżeństwa doczekał się syna Wilhelma (1525-1567). Młodszy z synów Zygmunta Kurzbacha zmarł w 1533 r. Anna von Kurzbach, będąca zapewne najmłodszym dzieckiem swoich rodziców, została zakonnica. Zmarła 30 stycznia 1560 r. jako przeorysza klasztoru św. Klary we Wrocławiu ${ }^{3}$.

Przyznać trzeba, że na podstawie przedstawionych informacji trudno powiedzieć coś więcej tak o Zygmuncie von Kurzbachu, jak i o jego małżonce. Dzięki badaniom i materiałom archiwalnym zgromadzonym przez Włodzimierza Dworzaczka możemy jednak dowieść, że Zygmunt von Kurzbach miał $z$ małżeństwa $z$ Dorota von Helfenstein nie troje, a co najmniej czworo dzieci. Jego druga, nieznaną większości historyków niemieckich, córka była bowiem Ludmiła von Kurzbach. W moim przekonaniu, była ona najstarszym dzieckiem Zygmunta i Doroty. Po raz pierwszy wspomniano o niej w dwóch dokumentach pochodzacych z 1506 r., kiedy była już żona przedstawiciela wielkopolskiej rodziny możnowładczej, kasztelanica kamieńskiego Jana Bnińskiego herbu Łodzia4. W pierwszym ze źródeł Mikołaj Kobyliński i Maciej Witkowski zaręczaja, że ojciec Ludmiły, Zygmunt Korzbok z Witkowa, pan na Żmigrodzie (Straburku), wypłaci jej mężowi posag w wysokości 500 złotych węgierskich, a Jan Bniński składa zobowiązanie, że uwolni swoje dobra od wszelkich ciężarów i oprawi na nich posag małżonki ${ }^{5}$. W drugim dokumencie Jan Bniński dokonuje oprawy 600 złotych węgierskich

${ }^{3}$ Por. J. Sinapius, op. cit., s. 203-205; J.C. Is elin, op. cit., s. 61; N. Pol, Jahrbücher der Stadt Breslau, Bd. IV, Breslau 1823, s. 50, 98-99; K.A. Mü11er, op. cit., s. 200-201; O.L. Goed sche, op. cit., s. 10-13; W. Dworzaczek, Genealogia, t. II (Tablice), Warszawa 1959, tabl. 133. Podobnie jak w przypadku ich ojca, nie znamy dat urodzin wspomnianych tu dzieci Zygmunta Kurzbacha. Należy jednak przestrzec przed próbami dopasowywania daty urodzin Jana (Johanna) do daty urodzin jego pierwszej żony. W moim przekonaniu, urodził się on bowiem ok. 1590 r. i był zapewne kilkanaście lat młodszy od księżniczki Salomei żagańskiej. Henryk i Anna przyszli zapewne na świat w ostatniej dekadzie XV stulecia.

${ }^{4}$ Por. Biblioteka Kórnicka PAN [dalej: BKPAN], Teki Dworzaczka [dalej: TD], Monografie, Bnińscy herbu Łodzia. Warto zwrócić uwage na fakt, że tylko jeden $z$ cytowanych wyżej historyków niemieckich wśród dzieci Zygmunta von Kurzbacha wymienił Ludmiłę. Co więcej, jego zdaniem Zygmunt miał również córki Małgorzatę i Barbarę. Por. N. Pol, op. cit., Bd. II, s. 199.

${ }^{5}$ Por. BKPAN, TD, Grodzkie i ziemskie, Poznań, Inskrypcje, XVI wiek, Część 1, 411 (Nr. 862), 1506, f. 107v. 
posagu i takiej samej sumy wiana na należących do niego dobrach na rzecz żony, Ludmiły z Milicza, córki Zygmunta Korzboka, liberi domini na Straburku i Miliczu6. W 1520 r. Jan Bniński zapisał swojej żonie Ludmile, córce nieżyjącego już Zygmunta, wolnego pana na Straburku i Miliczu, dożywocie na połowie miasta Bnina i wsi przyległych, a opiekunem synów na wypadek swojej śmierci uczynił jej rodzonego brata - Jana Korzboka ze Straburka i Milicza ${ }^{7}$. W 1524 r., na mocy zmienionego nieco rozporządzenia, Jan Bniński powierzył opiekę nad synami oraz należnym im majątkiem żonie, Ludmile $z$ Milicza oraz jej bratu, Janowi Korzbokowi, baronowi z Milicza ${ }^{8}$. Jan Bniński żył jeszcze w 1534 r. Jako zmarły odnotowany został w roku następnym. Pozostawił po sobie trzech synów - Stanisława, Jana i Andrzeja oraz córki: Agnieszkę, żonę Mikołaja Ksiąskiego; Dorotę, żonę Mikołaja z Konar Malechowskiego, a następnie Mikołaja $z$ Konar Kołaczkowskiego; Ludmiłę, żonę Andrzeja Witosławskiego; Jadwigę, wydana najpierw za Jana Golińskiego, a następnie za Jana (Janusza) Słomowskiego; Katarzynę, zamężna za Stanisławem Siedleckim; oraz Barbarę, poślubioną Stanisławowi Dobrzyckiemu9. Wdowa po Janie w 1545 r., słaba już na zdrowiu, dała ze swojej sumy oprawnej zabezpieczonej na dobrach boreckich po 100 złotych córkom Agnieszce, Dorocie, Ludmile, Jadwidze i Katarzynie, a 200 złotych najmłodszej Barbarze ${ }^{10}$. Ludmiła $z$ Milicza Bnińska zmarła zapewne wkrótce potem. Nie żyła już na pewno w 1549 r. ${ }^{11}$

Zachowane w aktach wielkopolskich przekazy źródłowe w sposób jednoznaczny potwierdzają, że Zygmunt von Kurzbach, wolny pan na Miliczu i Żmigrodzie (Straburku), był szlachcicem polskim ${ }^{12}$.

${ }^{6}$ Por. BKPAN, TD, Grodzkie i ziemskie, Poznań, Rezygnacje, XV wiek, Część 1, 7258 (Nr. 1390), 1506, f. 80v. Zwróćmy uwagę na to, że Jan Bniński oprawił posag żony na trzeciej części miasta Borek, trzeciej części wsi Skokowo, Zdziesz, Trzecianowo i Stawiszynek, szóstej części wsi Bruczkowo i Zalesie oraz na całej wsi Bartoszewice. Por. też ibidem, Monografie, Bnińscy herbu Łodzia.

7 Por. BKPAN, TD, Grodzkie i ziemskie, Poznań, Rezygnacje, XVI wiek, 4678 (Nr. 1392), 1520, f. 368v; oraz ibidem, Monografie, Bnińscy herbu Łodzia.

${ }^{8}$ Por. BKPAN, TD, Grodzkie i ziemskie, Poznań, Rezygnacje, XVI wiek, 5449 (Nr. 1393), 1524, f. 38v.

${ }^{9}$ Por. BKPAN, TD, Monografie, Bnińscy herbu Łodzia.

10 Por. BKPAN, TD, Grodzkie i ziemskie, Rezygnacje, XVI wiek, 2745 (Nr. 1395), 1545, f. 225.

${ }^{11}$ Por. BKPAN, TD, Monografie, Bnińscy herbu Łodzia.

${ }^{12}$ Fakt ten znany był również niektórym historykom niemieckim. Już O.L. Goedsche podał informację, że w 1514 r. synowie Zygmunta sprzedali Witkowo i inne 
$\mathrm{Na}$ ich podstawie możemy również ustalić, jak nazywali się jego rodzice. Przypomnijmy, że jeszcze w cytowanych już dokumentach z 1506 r. został on nazwany Korzbokiem $z$ Witkowa. Tego nazwiska używał również wcześniej. W 1485 r. Zygmunt Korzbok Witkowski części dziedziczne we wsiach Grzybowo, Wołowe i Suchodól, które nabył za 50 grzywien od Stanisława Broniewskiego, sprzedał Władysławowi z Głęboczka, doktorowi dekretów oraz kanonikowi poznańskiemu i gnieźnieńskiemu ${ }^{13}$. W roku następnym ten sam Zygmunt, syn nieżyjącego już Piotra Witkowskiego, miał sprawę $z$ braćmi Janem i Stanisławem $z$ Gurowa ${ }^{14}$. Stanowi to, jak się wydaje, wystarczające potwierdzenie tego, że późniejszy baron na Miliczu i Żmigrodzie pochodził $z$ rodziny Korzboków osiadłych w Witkowie w powiecie gnieźnieńskim. Był synem Piotra Korzboka $z$ Witkowa (zm. p. 1486), który odnotowywany był w księgach poznańskich w latach $1449-1480^{15}$. Żona Piotra, i bez watpienia matka Zygmunta, była natomiast Ludmiła Głębocka $z$ Głęboczka herbu Łodzia, córka Piotra (zm. po 1453), kasztelana rogozińskiego. To właśnie ona, występująca w źródle jako córka nieżyjącego już Piotra Głębockiego i żona Piotra Witkowskiego, pozywała w 1475 r. Pawła Budziszewskiego o prawo bliższości do dóbr Głęboczek, należących niegdyś do jej ojca i matki ${ }^{16}$. W 1486 r., będąc już wdową po Piotrze

dobra po ojcu w powiecie gnieźnieńskim za 100 guldenów swojemu „stryjowi” Maciejowi Kurzbachowi. Por. idem, op. cit., s. 10. Dodajmy w tym miejscu, że Kurzbachowie używali herbu Korzbok, który przedstawiał „Trzy karpie złote... jeden nad drugim pływające w polu białem, na hełmie pięć piór strusich”. Por. K. Nie si e cki, Herbarz polski, wyd. J.N. Bobrowicz, t. V, Lipsk 1840, s. 257. Warto jednak powiedzieć, że w niektórych odmianach tego herbu zamiast karpi pojawiały się inne ryby, a pole bywało też niebieskie lub czerwone.

${ }_{13}$ Por. BKPAN, TD, Grodzkie i ziemskie, Poznań, Rezygnacje, XV wiek, Część 1, 5771 (Nr. 1387), 1485, f. 16.

14 Por. BKPAN, TD, Grodzkie i ziemskie, Gniezno, Część 2, 2264 (Nr. 22), 1486, f. 43.

15 Por. BKPAN, TD, Grodzkie i ziemskie, Gniezno, Część 2, 1774 (Nr. 7), 1449, f. 14v; Grodzkie i ziemskie, Poznań, Rezygnacje, XV wiek, Część 1, 388 (Nr. 1381), 1450, f. 103; 2725 (Nr. 20), 1468, f. 159v; 9642 (Nr. 9 gr. 1386), 1480, f. 198v. Zupełnie nieuprawnione sa podejmowane niekiedy próby identyfikowania ojca Zygmunta Korzboka $z$ Milicza $z$ podkomorzym poznańskim Piotrem Korzbokiem (zm. 1438). Nie jest jednak powiedziane, że Piotr Korzbok z Witkowa nie mógł być wnukiem podkomorzego. Por. A. Gas siorowski, Korzbok (Korczbok, Korczborg) Piotr, [w:] PSB, t. XIV, Wrocław-Warszawa-Kraków 1968-1969, s. 159.

16 Por. BKPAN, TD, Grodzkie i ziemskie, Rezygnacje, XV wiek, Część 2, 854 (Nr. 21zs), 1475, f. 23v. Więcej informacji na temat ojca Ludmiły, kasztelana rogozińskiego Piotra Głębockiego por. Słownik historyczno-geograficzny województwa 
Korzboku $z$ Witkowa, miała $z$ kolei sprawę $z$ Janem Korzbokiem z Rybna, w której jako arbitrzy występowali Mikołaj z Kutna, wojewoda łęczycki i generał wielkopolski, Sędziwój Czarnkowski, kasztelan santocki, oraz Maciej Słupski, kasztelan nakielski ${ }^{17}$. Wypada zatem raz jeszcze stwierdzić, że pierwszy władca państwa milicko-żmigrodzkiego pochodził $z$ Wielkopolski i był bez wattpienia synem Piotra Korzboka $z$ Witkowa oraz kasztelanki rogozińskiej Ludmiły Głębockiej. To właśnie imię po swojej babce (bardzo rzadkie w tym czasie wśród szlachty wielkopolskiej) otrzymała najstarsza córka Zygmunta Korzboka, w historiografii niemieckiej konsekwentnie nazwanego Kurzbachem, która poślubiwszy Jana Bnińskiego, powróciła na zawsze do ojczyzny swojego ojca.

Wyjaśniwszy tajemnicę pochodzenia Zygmunta Korzboka vel Kurzbacha, możemy przejść do próby odpowiedzi na pytanie postawione w tytule tego artykułu. W ślad za historiografia niemiecka zakładam, że żona pierwszego barona na Miliczu i Żmigrodzie rzeczywiście była hrabianka Dorota von Helfenstein. Zanim jednak spróbujemy rozwikłać związane $z$ jej osoba zagadki genealogiczne, musimy rozwiać wątpliwość zasadniczej natury i odpowiedzieć na pytanie, jak mogło dojść do mariażu dworzanina Władysława II Jagiellończyka, czynnego w początkach swojej kariery przede wszystkim na terenie Czech, $z$ przedstawicielka rodziny mającej swoje posiadłości na terenie stosunkowo odległej Szwabii? Na szczęście w tym przypadku odpowiedź jest prosta. Otóż zubożały ród hrabiów von Helfenstein pozostawał w dość bliskich relacjach $z$ frankońską linia Hohenzollernów, panów na Ansbach, której przedstawiciele piastowali również godność elektorów brandenburskich. Męscy potomkowie rodu przyjmowali służbę u margrabiów, a na ich dwór, do fraucymerów trafiały hrabianki. Wiemy na pewno, że przedstawiciele rodu von Helfenstein bywali na dworach Fryderyka II Żelaznego, elektora brandenburskiego w latach 1440-1471, oraz jego młodszego brata Albrechta III Achillesa, margrabiego na Ansbach od 1440 r. i elektora brandenburskiego w latach $1471-1486^{18}$. Od-

poznańskiego $w$ średniowieczu, cz. 1, oprac. S. Chmielewski, K. Górska-Gołaska, J. Luciński, Wrocław 1982-1987, s. 485.

17 Por. BKPAN, TD, Grodzkie i ziemskie, Gniezno, Część 2, 2218 (Nr. 22), 1486, f. 19.

18 Por. K. Gruber, Heiratsfrage als Problem, „Geislinger Zeitung”, 25 II 2015, Südwest Presse online; idem, Sorge um das Lehen, ibidem, 13 III 2015; idem, 300 Gulden bei Heirat, ibidem, 5 III 2015. 
notowane $\mathrm{w}$ źródłach związki rodu von Helfenstein $z$ panami na Ansbach pozwalają nam znaleźć trop wiodący do mariażu Zygmunta Korzboka $z$ Witkowa $z$ hrabianka Dorota. Dnia 20 sierpnia 1476 r. we Frankfurcie nad Odra Władysław II Jagiellończyk poślubił bowiem per procura 12-letnia Barbarę Hohenzollern, córkę margrabiego brandenburskiego Albrechta III Achillesa, wdowę po Henryku XI ks. głogowskim. I chociaż małżeństwo to nie zostało dopełnione, a małżonkowie nigdy się nie spotkali, gdyż Władysław bardzo szybko stracił zainteresowanie dla tego związku (ożenił się $z$ myślą o włączeniu do domeny królewskiej księstwa głogowskiego, które ostatecznie zostało opanowane przez księcia żagańskiego Jana II Szalonego), to jednak podejmowane przez króla czeskiego zabiegi o jego unieważnienie trwać miały aż do końca XV stule$\mathrm{cia}^{19}$. Niespełna trzy lata po tym mariażu, 14 lutego 1479 r. Fryderyk Hohenzollern, młodszy syn Albrechta III Achillesa poślubił we Frankfurcie nad Odrą Zofię Jagiellonkę, córkę króla polskiego Kazimierza IV Jagiellończyka i siostrę króla czeskiego Władysława II ${ }^{20}$. Jak można przypuszczać, również to małżeństwo przyczyniło się w znaczącym stopniu do ożywienia kontaktów między dworem praskim a margrabiami na Ansbach. Być może podczas jakiejś wizyty na frankońskim dworze Hohenzollernów, posłujący w imieniu króla czeskiego Zygmunt Korzbok $z$ Witkowa poznał hrabiankę Dorotę von Helfenstein, pannę $z$ fraucymeru Zofii Jagiellonki, która została w przyszłości jego żoną. Wydaje się to wielce prawdopodobne.

Jak więc widzimy, żona pierwszego barona na Miliczu i Żmigrodzie rzeczywiście mogła pochodzić $z$ rodu hrabiów von Helfenstein. Warto więc w tym miejscu przybliżyć nieco dzieje tej rodziny. Jej nazwisko pochodzi od zamku Helfenstein, usytuowanego niedaleko miasta Geislingen an der Steige w Szwabskiej Jurze. Hrabiowie

19 Por. C. Grünhagen, Barbara, Markgräfin von Brandenburg, [w:] Allgemeine Deutsche Biographie, Bd. II, Leipzig 1875, s. 49-50; K. Pi e radzka, Henryk XI, [w:] PSB, t. IX, Wrocław-Warszawa-Kraków 1960-1961, s. 415. Dodajmy w tym miejscu, że zabiegi Władysława II o unieważnienie małżeństwa były paraliżowane przez elektora brandenburskiego, który konsekwentnie dążył do tego, aby jego córka zasiadła na tronie czeskim. Cała ta sprawa musiała pociagnać za soba ożywienie kontaktów dyplomatycznych między dworem praskim a Hohenzollernami. Warto również wspomnieć o tym, że w roku 1490, będąc nadal mężem Barbary, król czeski poślubił Beatrycze Aragońską, wdowę po Macieju Korwinie. Oba te małżeństwa zostały unieważnione przez papieża Aleksandra VI w $1500 \mathrm{r}$.

${ }^{20}$ Por. Z. W d ow is zew s ki, Genealogia Jagiellonów i Domu Wazów w Polsce, wyd. 2, Kraków 2005, s. 110-112; U. Borkows ka, Dynastia Jagiellonów w Polsce, Warszawa 2011, s. 517. 
używali herbu przedstawiającego srebrnego słonia nad trzema złotymi pagórkami na czerwonym tle. Największe znaczenie osiagnęli w XIII i XIV stuleciu. W 1356 r. doszło do podziału hrabstwa. Dotychczasowy hrabia von Helfenstein (od 1340 r.) Ulryk V Starszy ustapił $z$ części dóbr i przyjał tytuł hrabiego von Helfesntein-Wiesensteig (był nim w latach 1356-1372). Od niego wywodzi się starsza linia rodu von Helfenstein. Brat stryjeczny Ulryka V - Ulryk VI Młodszy (zm. 1361), protoplasta drugiej, młodszej gałęzi rodziny, został w 1356 r. pierwszym hrabia von Helfenstein-Blaubeuren ${ }^{21}$. Pod koniec XIV w. hrabiowie von Helfenstein, którzy dysponowali bardzo znacznymi dobrami ziemskimi na terenie Szwabii, zaczęli popadać w trudności finansowe. Już w 1382 r. hrabia Fryderyk I von Helfenstein-Wiesensteig zaciagną $\mathrm{w}$ wolnym mieście cesarskim Ulm pożyczkę, którą zabezpieczył na rodowym zamku i hrabstwie Geislingen. W kolejnych latach obciążał swoje dobra kolejnymi pożyczkami. Kiedy zaś wreszcie w 1396 r. rada miejska Ulm zażądała zwrotu pożyczonych pieniędzy, okazało się, że dług hrabiego wynosi olbrzymią kwotę niemal 124 tys. guldenów. Nie dysponując rzecz jasna taką gotówką, Fryderyk I zmuszony był przekazać swoim wierzycielom zamek Helfenstein wraz $z$ miastem Geislingen oraz blisko 30 wsiami wchodzacymi w skład hrabstwa bioracego swoją nazwę od wspomnianego tu miasteczka ${ }^{22}$. W pierwszej połowie XV stulecia również przedstawiciele młodszej gałęzi rodu w podobny sposób zadłużyli swoje majątki. W latach 1447-1448, naciskani przez coraz bardziej natarczywych wierzycieli, hrabiowie Ulryk VIII i Konrad II von Helfenstein-Blaubeuren sprzedali znaczącą większość swoich posiadłości władcom Wirtembergii ${ }^{23}$. Oznacza to, że już w połowie XV w. obie linie rodu von Helfenstein wyzbyły się znacznej części swoich starych majątków, tracąc dotychczasowe wpływy i znaczenie polityczne. Co w tym wszystkim wydaje

${ }^{21}$ Por. H.F. Ke rle r, Geschichte der Grafen von Helfenstein, Ulm 1840, s. 1-54, zwłaszcza 55-56 (tu o podziale hrabstwa i dobrach, które przypadły hrabiom na Wiesensteig i Blaubeuren). Por. też Graf Helffensteinischer Theil-Bref der Graf und Herrschaft Helfenstein, de 1356, Urkunden zur Geschichte der Grafen von Helfenstein, hrsg. von H.F. Kerler [dalej: Kerler, Urkunden], Ulm 1840, s. 11-12; oraz Graf Helffensteinischer Theil-Bref der Graf und Herrschaft Helffenstein, de Anno 1356 vidimirt de Anno 1360, ibidem, s. 12-14.

${ }^{22}$ Por. H.F. Kerler, op. cit., s. 80-88; oraz Graff Helffensteinicher Berglich, Berzücht und Ubergab der alleniret Helffensteinischer Gütter, gegen der Stadt Ulm, de Anno 1396, Kerler, Urkunden, s. 23-33.

${ }^{23}$ Por. H.F. Kerler, op. cit., s. 97-98, 101; oraz Extract des Kaufbriefs von Blaubeuren vom Jahr 1447, Kerler, Urkunden, s. 33-34. 
się jednak najciekawsze, to to, że prawdopodobnie właśnie dlatego, niezbyt jeszcze majętny dworzanin króla czeskiego, jakim w połowie lat osiemdziesiatych XV w. był bez watpienia Zygmunt Korzbok z Witkowa, mógł podjąć, zakończone w ostatecznym rozrachunku powodzeniem, starania o rękę przedstawicielki tego niegdyś świetnego, ale podupadłego już rodu.

Kolejną przeszkodą, którą musimy przezwyciężyć, rozwiązując zagadkę pochodzenia hrabianki Doroty, jest to, że żadna genealogia rodu von Helfenstein nie potwierdza jej istnienia. Nie jest to jednak bynajmniej argument rozstrzygający. Często bowiem zdarzało się, że córka stosunkowo wcześnie opuszczająca dom rodzinny nie została odnotowana we współczesnych źródłach. Pomijanie w różnego rodzaju genealogiach córek, które zostały zakonnicami, jest zjawiskiem dość powszechnym. Często zdarzało się jednak również, że nie wspominano o kobietach, które pozostawiły po sobie ewidentne dowody istnienia, zapisując się wyraźnie na kartach historii. Dość wspomnieć tutaj chociażby opisany przeze mnie przypadek Anny $z$ Lanckorońskich $1^{\circ}$ v. Świerszczowej, $2^{\circ}$ v. Piaseckiej, $3^{\circ}$ v. Herburtowej, której próżno szukać w jakiejkolwiek genealogii znanej przecież rodziny Lanckorońskich herbu Zadora ${ }^{24}$. W przeciwieństwie do innych badaczy, którzy usiłowali poszukiwać rodziców hrabianki Doroty bez zwracania uwagi na chronologię wydarzeń, dysponuje niezmiernie ważną informacją o dacie ślubu jej córki. Zakładam, że skoro Ludmiła Korzbokówna $z$ Milicza wyszła za Jana Bnińskiego w 1506 lub w 1505 r., to musiała urodzić się najpóźniej w 1490 r. Prawdopodobnie jednak jej datę urodzenia należałoby przesunąć na rok 1487 lub 1488. Oznacza to, że jej matka, hrabianka Dorota von Helfenstein przyszła na świat najpewniej w przedziale czasowym zawartym między 1465 a 1470 r., a poślubiła Zygmunta Korzboka w 1485 lub 1486 r. To z kolei pozwala nam na zdecydowane zawężenie obszaru poszukiwań.

W pierwszej kolejności dokonamy selekcji negatywnej, wykluczając tych członków rodu hrabiów von Helfenstein żyjących w latach sześćdziesiątych i siedemdziesiątych XV w., którzy nie mogli być ojcami interesujacej nas hrabianki. Starsza linia rodu reprezentowana była w tym czasie przez trzech dorosłych mężczyzn - Ludwika III, jego młodszego brata Fryderyka II oraz syna tego ostatniego

${ }^{24}$ Por. Z. Anusik, Zapomniana panna Lanckorońska. Przyczynek do genealogii kilku rodzin kresowych, „Przegląd Nauk Historycznych” 2017, R. XVI, nr 1, s. 301-324. 
- Ludwika IV. Najstarszym $z$ nich był Ludwik III hr. von Helfenstein-Wiesensteig (zm. 1493), syn Fryderyka I (zm. 1438), wnuk Ulryka V Młodszego, który w 1472 r. poślubił hrabiankę Amalię von Oettingen-Wallerstein (zm. 1487/1501). Późno zawarte małżeństwo (w chwili ślubu Ludwik miał ok. 60 lat) było jednak bezdzietne ${ }^{25}$. Młodszy brat Ludwika III - Fryderyk II (zm. 1483) żenił się dwukrotnie. Po raz pierwszy z Agnieszką von Eberstein (zm. 1456), z która miał syna Ludwika IV (1447-1493). Druga żoną Fryderyka została $z$ kolei w 1476 r. Irmengarda (Irmgard) hrabianka von Helfenstein-Blaubeuren, która urodziła mu syna Fryderyka III ${ }^{26}$. Pierwsza żona Fryderyka II zmarła zbyt wcześnie, żeby mogła być matką Doroty. Nie mogła być nią również jego druga żona, gdyż jej małżeństwo z Fryderykiem II zostało zawarte zbyt późno. Najmłodszy z tej trójki, Ludwik IV hr. von Helfenstein-Wiesensteig był jedynym synem Fryderyka II i jego pierwszej żony Agnieszki von Eberstein. W 1483 r. poślubił Elżbietę von Limpurg-Speckfeld (zm. 1538), córkę Jerzego II i Małgorzaty von Zollern-Hohenberg. $Z$ tego małżeństwa doczekał się sporej gromadki dzieci: synów Ulryka X (1486-1548), zmarłego w dzieciństwie Ludwika (1488-1489), i drugiego Ludwika, znanego jako Ludwik V Helferich (1493-1525) oraz córek: wspomnianej wcześniej Agnieszki (1484-1550), która w 1500 r. poślubiła Wilhelma von Ilburg-Ronov, Małgorzaty (ur. 1489), która w 1506 r. wyszła za mąż za Oswalda barona von Wolkenstein, Barbary (1490-1557) i Apolonii (1492-1537). Dwie najmłodsze córki Ludwika IV zostały zakonnicami. Wdowa po Ludwiku IV hr. von Helfenstein-Wiesensteig w 1495 r. wyszła ponownie za mąż za dalekiego kuzyna swojego pierwszego męża - Jerzego I hr. von Helfenstein-Blaubeuren ${ }^{27}$. Z oczywistych względów również i Ludwik IV

${ }^{25}$ Por. H.F. Kerler, op. cit., s. 115-116; D. Schwennicke, Europäische Stammtafeln. Stammtafeln zur Geschichte der Europäische Staten, Neue Folge [dalej: Europäische Stammtafeln], Bd. XII (Schwaben), Marburg 1992, Tafel 58; H. Büchler, Adel, Klöster und Burgherren ins alten Herzogtum Schwaben, Gesammelte Aufsätze, hrsg. von W. Ziegler, Weissenhom 1997, s. 967.

${ }^{26}$ Por. H.F. Kerler, op. cit., s. 118-124; Europäische Stammtafeln, Bd. XII, Tafel 58, 60 (dotyczy drugiej żony hrabiego Fryderyka); Bd XVI (Bayern und Franken), Marburg 1995, Tafel 29 (dotyczy pierwszej żony hrabiego Fryderyka); H. Büchler, op. cit., s. 966.

${ }_{27}$ Por. H.F. Ke rle r, op. cit., s. 124-125; Europäische Stammtafeln, Bd. XII, Tafel 58; Bd. XVI, Tafel 140 (dotyczy żony hrabiego Ludwika). H. Bü chler, op. cit., s. 967. Wypada zwrócić w tym miejscu uwagę na fakt, że Elżbieta von Limpurg-Speckfeld była jedyna żona Ludwika IV. Pojawiajace się na niektórych stronach internetowych informacje, że jego pierwszą żoną była Amalia von Oettingen-Wal- 
von Helfenstein-Wiesensteig nie mógł być ojcem hrabianki Doroty. Jedynie jako swego rodzaju ciekawostkę można więc przytoczyć informację, że twórcy jednej $z$ najbardziej popularnych w Polsce genealogicznych stron internetowych, opierajac się na ustaleniach bliżej niezidentyfikowanego (prawdopodobnie angielskiego) genealoga, opracowującego wywód przodków Karola ks. Walii i jego żony Diany Spencer, przyjęli za pewnik że Dorota von Helfenstein, żona Zygmunta Kurzbacha, barona na Miliczu i Żmigrodzie, była jedna $z$ córek Ludwika IV i Elżbiety von Limpurg-Speckfeld ${ }^{28}$. Aby zdezawuować to twierdzenie, wystarczy powiedzieć, że sądząc na podstawie daty ślubu jej rodziców, Elżbieta von Limpurg-Speckfeld urodziła się nie wcześniej niż w 1466 r. Była więc prawdopodobnie rówieśnica swojej domniemanej córki.

Młodszą linię hrabiów von Helfenstein reprezentowali w latach sześćdziesiątych i siedemdziesiątych XV w. również trzej dorośli mężczyźni. Najstarszym $z$ nich był Ulryk VIII hr. von Helfenstein-Blaubeuren (ok. 1408-1503), syn Jana II (zm. 1444) i hrabianki Irmgard von Kirchberg, wnuk Ulryka VI Młodszego. Był on jednak kawalerem, zatem nie może być brany pod uwage jako potencjalny ojciec hrabianki Doroty ${ }^{29}$. Śmiało możemy również wykluczyć jego bratanka - Jerzego I (zm. 1517). Po raz pierwszy ożenił się on bowiem dopiero w 1476 r. Jego żoną została wówczas Cecylia von Truchtelfingen, wdowa po Johannie von Hexennager. Po bezpotomnej śmierci pierwszej żony hrabia Jerzy poślubił w 1495 r. wdowę po Ludwiku IV hr. von Helfenstein-Wiesensteig, Elżbietę von Lim-

lerstein sa nieprawdziwe. W tym przypadku chodzi bowiem o żonę jego stryja Ludwika III, co ewidentnie wynika ze źródła cytowanego we wskazanym przeze mnie miejscu w pracy H. Büchlera.

${ }_{28}$ Por. Urszula Ledóchowska - królewskie pochodzenie, Genealogia Polaków, Dynamiczny Herbarz Rodzin Polskich, http://genealogia.okiem.pl/tron/ledochow ska_urszula.htm (dostęp: 15 XI 2017 r.). Dodam tylko w tym miejscu, że cały przedstawiony tu wywód genealogiczny św. Urszuli Ledóchowskiej został oparty na błędnych przesłankach. Pomijając już nawet fakt, że Dorota von Helfenstein na pewno nie była córką wskazanych tu rodziców, należałoby jeszcze dodać, że matka jednego z przodków Doroty - hrabiego Ulryka II (VI) nie była wcale Anna von Henneberg, jak twierdzą twórcy tego wywodu, ale nieznana $z$ imienia przedstawicielka rodu von Ravenstein. To $z$ kolei sprawia, że można ponad wszelką wątpliwość wykluczyć pochodzenie Urszuli Ledóchowskiej od Mieszka III Starego. Rzecz jasna, nie oznacza to wcale, że wśród przodków Doroty von Helfenstein nie było przedstawicieli dynastii panującej w Polsce. Według moich ustaleń jej przodkami w ósmym pokoleniu byli bowiem Ulryk I hr. Wirtembergii i Agnieszka ks. legnicka, córka słynnego i osławionego Bolesława Rogatki.

${ }^{29}$ Por. H.F. Kerler, op. cit., s. 97-101; Europäische Stammtafeln, Bd. XII, Tafel 60. 
purg-Speckfeld. Miał z nią dwóch synów o imieniu Wilhelm, którzy zmarli w dzieciństwie, oraz córki: Urszulę (1496-1576), przeoryszę w klasztorze w Kirchheim unter Teck, zmarłe w dzieciństwie Magdalenę (ur. 1497), Agatę (ur. 1502), Dorotę (ur. 1503) i Annę oraz urodzona w $1509 \mathrm{r}$. Wandelbergę, którą wydano w przyszłości za mąż za Fryderyka barona von Schwarzenberg ${ }^{30}$. Jak widzimy, oba małżeństwa hrabiego Jerzego zostały zawarte zbyt późno, aby mógł on być ojcem interesującej nas Doroty.

Jedynym męskim potomkiem rodu von Helfenstein, który mógł być ojcem żony Zygmunta Kurzbacha $z$ Milicza i Żmigrodu jest hrabia Konrad II von Helfenstein-Blaubeuren (zm. 1474), młodszy brat Ulryka VIII i ojciec Jerzego I. Urodzony ok. 1410 r., był drugim synem Jana II hr. von Helfenstein-Blaubeuren i Irmgard von Kirchberg. Jak można przypuszczać, początkowo przeznaczony był do stanu duchownego. W 1425 r. został bowiem kanonikiem przy katedrze w Strasburgu. Dość szybko jednak porzucił tę drogę kariery. W 1445 r., w rok po śmierci ojca, przeprowadził ze starszym bratem podział rodowego majątku. Konrad objął dobra Blaubeuren, a Ulryk - włość Brenztal. Bardzo szybko bracia rozpoczęli jednak wyprzedaż obciążonych znacznymi długami dóbr ziemskich odziedziczonych po przodkach. Poczattkowo sprzedawali jedynie pojedyncze wioski. Już w 1447 r. Konrad sprzedał cały klucz Blaubeuren Ludwikowi hr. Wirtemberskiemu $z$ linii na Urach, a w poczatkach $1448 \mathrm{r}$. Ulryk wyzbył się majątku Brenztal na rzecz Ulryka hr. Wirtemberskiego $z$ linii na Stuttgarcie. W tym samym roku hrabia Konrad kupił za 4000 guldenów niewielki majątek Wellheim, lenno margrabiów brandenburskich na Ansbach, który od tej pory stanowił główna posiadłość tej linii rodu. Pod względem majątkowym hrabiowie von Helfenstein spadli więc do poziomu średniozamożnej szlachty. Do niedawna uważano, że Konrad II miał tylko jedną żonę - Urszulę von Seckendorff, która miała być matka wszystkich jego dzieci. A była ich całkiem spora gromadka - autorzy różnych genealogii hrabiów von Helfenstein uważają bowiem, że hrabia Konrad miał na pewno pięciu synów i co najmniej pięć córek. Nie wykluczają jednak, że mógł mieć jeszcze synów Krzysztofa i Fryderyka oraz córkę Urszulę ${ }^{31}$ W moim przekonaniu w wyliczeniu tym należałoby

${ }^{30}$ Por. H.F. Kerler, op. cit., s. 102-104; Europäische Stammtafeln, Bd. XII, Tafel 60; Bd. XVI, Tafel 140 (dotyczy drugiej żony hrabiego Jerzego).

${ }^{31}$ Por. H.F. Kerle r, op. cit., s. 99-101, 104; Europäische Stammtafeln, Bd. XII, Tafel 60; H. Büchler, op. cit., s. 316, 179, 418, 432-433, 568, 673, 964, 1096; K. Gruber, Sorge um das Lehen. 
uwzględnić również interesująca nas hrabiankę Dorotę. Tu pojawia się jednak kolejna wątpliwość. Ponieważ w żadnej ze starszych genealogii rodziny Konrada II von Helfenstein-Blaubeuren nie podano daty zawarcia przez niego małżeństwa, należałoby wziąć pod uwagę możliwość, że urodzony ok. 1410 r. hrabia mógł się ożenić już w latach trzydziestych XV w. Rodziłoby to $z$ kolei pytanie o to, czy jego żona, urodzona ok. 1420 r., mogłaby być matka córki, która przyszła na świat niemal 50 lat później? Na szczęście niemiecki historyk Karlfriedrich Gruber dotarł do źródeł, które rzucaja zupełnie nowe światło na sytuację rodzinna pana na Wellheim. Okazuje się bowiem, że hrabia Konrad II żenił się nie raz, a dwa razy. Jego pierwszą żona była poślubiona między 1442 a 1448 r. Dorota von Seckendorff-Abardar, która zmarła w 1455 r. Po śmierci pierwszej żony, 11 sierpnia 1456 r. hrabia ożenił się po raz drugi. Tym razem jego wybranka była znana już nam Urszula von Seckendorff-Rinhofen. Karlfriedrich Gruber twierdzi, że niemożliwe jest ustalenie, które dzieci Konrada (wspomina o pięciu synach i pięciu córkach) pochodziły $z$ pierwszego, a które $z$ drugiego małżeństwa ${ }^{32}$. Ja jednak zaryzykuję stwierdzenie, że Dorota von Seckendorff-Abardar urodziła mężowi 4 lub 5 córek, a Urszula von Seckendorff-Rinhoffen wszystkich synów i dwie najmłodsze córki.

W tym przypadku wystarczy zresztą odwołać się do chronologii. Najstarszą córką hrabiego Konrada była Sybilla, która już w 1467 r. została benedyktynka w klasztorze Fraumünsters w Zurichu. W 1484 r. została tam przeorysza. Zmarła 11 maja 1487 r. Z cała pewnością była córką pierwszej żony Konrada II. Gdyby bowiem jej matka była Urszula von Seckendorff-Rinhoffen, do klasztoru wstępowałaby jako w najlepszym przypadku dziesięciolatka, co trzeba wykluczyć. Druga córka hrabiego na Wellheim była Cecylia, która została zakonnica w tym samym klasztorze co Sybilla. Trzecia Anna, która przywdziała habit dominikański, wstępując do klasztoru Mariental w Steinheim an der Murr. W 1478 r. została tu 20 przeoryszą $^{33}$. Czwartą córką Konrada II była Magdalena. Karlfriedrich Gruber uważa, że była ona najmłodsza córka hrabiego $z$ jego drugiego małżeństwa. Nie jest to jednak możliwe. Wiemy bowiem, że Magdalena była dwórką Anny, drugiej żony margrabiego Albrechta III Achillesa, i wraz z nią przeniosła się w 1471 r. z Ansbach do

${ }^{32}$ Por. K. Gruber, 300 Gulden bei Heirat; id e m, Sorge um das Lehen.

${ }^{33}$ Por. Europäische Stammtafeln, Bd. XII, Tafel 60; K. Gru be r, Im „Spital des Adels”, „Geislinger Zeitung”, 18 II 2015, Südwest Presse online. 
Berlina. Jeszcze w czasie pobytu we Frankonii młoda hrabianka złożyła obietnicę, że poślubi przedstawiciela niezbyt znaczącej rodziny szlacheckiej - Henryka von Selbitz. Próba unieważnienia tej obietnicy (a być może i potajemnie zawartego małżeństwa) stanowiła przedmiot zabiegów dyplomacji elektora brandenburskiego przynajmniej do 1474 r. ${ }^{34}$ Gdyby Magdalena rzeczywiście była córka Urszuli von Seckendorff-Rinhofen, to mogłaby się urodzić najwcześniej około 1460 r. (po Jerzym oraz Irmengardzie, których starszeństwo raczej nie podlega dyskusji) ${ }^{35}$. Trudno wyobrazić sobie, aby jako 10-11-latka mogła składać komukolwiek jakiekolwiek wiążące obietnice. Nie pozostaje więc nic innego, jak przyjąć, że Magdalena była czwartą, prawdopodobnie najmłodszą córką hrabiego Konrada $z$ jego małżeństwa $z$ Dorota von Seckendorff-Abardar ${ }^{36}$.

Najstarszym synem Konrada II $z$ drugiego małżeństwa był znany nam już Jerzy I. Urodzony zapewne w 1457 r. zmarł w roku 1517 jako ostatni męski potomek hrabiów von Helfenstein na Blaubeuren i Wellheim. Jego młodszymi braćmi byli: Bernard, Jan (Johann), Ernest (zm. 1483), kanonik w Augsburgu, Wolfgang, oraz być może Fryderyk i Krzysztof, kanonik w Ratyzbonie ${ }^{37}$. Wszyscy oni zmarli w młodym wieku i żaden $z$ nich nie pozostawił potomstwa. Rodzoną siostrą Jerzego I była też znana nam już Irmengarda. Być może najmłodszym dzieckiem, a $z$ pewnością najmłodszą córką Konrada II i Urszuli von Seckendorff-Rinhofen była też zapewne interesująca nas hrabianka Dorota. Wcześnie osierocona przez rodziców - Urszula zmarła 28 listopada, a Konrad 14 grudnia 1474 r., najpewniej szybko opuściła dom rodzinny, trafiając pod opiekę elektora brandenburskiego i margrabiego na Ansbach Albrechta III Achillesa. Jej dalszych losów możemy się tylko domyślać. Jeśli jednak

${ }^{34}$ Por. K. Gruber, Heiratsfrage als Problem.

${ }^{35}$ Zakładam, że Jerzy I był najstarszym synem Konrada II z jego małżeństwa $z$ Urszulą von Seckendorff-Rinhoffen. Świadczy o tym m.in. imię, jakie otrzymała jego najstarsza córka - Urszula. Urodził się zapewne w 1457 r., gdyż już w 1476 r. (majac lat 19) zawarł pierwsze małżeństwo. Irmengarda była zapewne jego rodzoną siostrą (Jerzy wydał ją za mąż, co wiązało się z koniecznością wypłacenia posagu), która musiała urodzić się zaraz po nim, gdyż w tym samym, 1476 r., mając lat siedemnaście lub osiemnaście, poślubiła hrabiego Fryderyka II von Helfenstein-Wiesensteig. Tak więc, kolejne dziecko Konrada II i jego drugiej małżonki mogło urodzić się najwcześniej około $1460 \mathrm{r}$.

${ }^{36}$ Nie jest jednak wykluczone, że $z$ pierwszego małżeństwa hrabiego Konrada pochodziła również, jeśli naprawdę była jego córką, hrabianka Urszula von Helfenstein, o której nie potrafimy powiedzieć nic bliższego.

${ }^{37}$ Por. H.F. Ke rler, op. cit., s. 104; Europäische Stammtafeln, Bd. XII, Tafel 60. 
żona Zygmunta Kurzbacha, barona na Miliczu i Żmigrodzie, rzeczywiście pochodziła $z$ rodu hrabiów von Helfenstein, to musiała być córką Konrada II na Wellheim i jego drugiej małżonki - Urszuli von Seckendorff-Rinhofen.

\section{Bibliografia}

\section{Ź RÓDEA DRUKOWANE}

Biblioteka Kórnicka PAN, Teki Dworzaczka

Codex Germaniae Diplomaticus, worinnen Viele wortrefliche und zum Theil noch niemahls Borheins genommene..., Frankfurt und Leipzig 1733.

Urkunden zur Geschichte der Grafen von Helfenstein, hrsg. von H.F. Kerler, Ulm 1840.

\section{OpRacowania}

Anusik Z., Zapomniana panna Lanckorońska. Przyczynek do genealogii kilku rodzin kresowych, „Przegląd Nauk Historycznych” 2017, R. XVI, nr 1, s. 301-324.

Biblioteka Kórnicka PAN, Teki Dworzaczka, Monografie, Bnińscy herbu Łodzia.

Borkowska U., Dynastia Jagiellonów w Polsce, Warszawa 2011.

Büchler H., Adel, Klöster und Burgherren ins alten Herzogtum Schwaben, Gesammelte Aufsätze, hrsg. von W. Ziegler, Weissenhom 1997.

Dworzaczek W., Genealogia, t. II (Tablice), Warszawa 1959.

Garbacik J., Jan I Olbracht, [w:] Polski słownik biograficzny, t. X, Wrocław-Warszawa-Kraków 1962-1964, s. 405-410.

Gąsiorowski A., Korzbok (Korczbok, Korczborg) Piotr, [w:] Polski słownik biograficzny, t. XIV, Wrocław-Warszawa-Kraków 1968-1969, s. 159-160.

Gebhard L.A., Geschichte aller Wendisch-Slavischen Staaten, Bd. III, Basel 1797.

Goedsche O.L., Geschichte und Statistik des Militsch-Trachenberg Kreises, Militsch-Breslau 1847.

Gruber K., 300 Gulden bei Heirat, „Geislinger Zeitung”, 5 III 2015, Südwest Presse online.

Gruber K., Heiratsfrage als Problem, „Geislinger Zeitung”, 25 II 2015, Südwest Presse online.

Gruber K., Im „Spital des Adels”, „Geislinger Zeitung”, 18 II 2015, Südwest Presse online.

Gruber K., Sorge um das Lehen, „Geislinger Zeitung”, 13 III 2015, Südwest Presse online.

Grünhagen C., Barbara, Markgräfin von Brandenburg, [w:] Allgemeine Deutsche Biographie, Bd. II, Leipzig 1875, s. 49-50. 
Heck R., Konrad X, [w:] Polski słownik biograficzny, t. XIII, Wrocław-WarszawaKraków 1967-1968, s. 595.

Hoffman K.G., Geschichte der Schleisen aus den ältesten Zeit bis aus unsere Tage, Bd. II, Schweidniz 1828.

Iselin J.C., Neu-vermehrtes Historisch- und Geographisches Allgemeines Lexicon, Bd. III, Basel 1745.

Kerler H.F., Geschichte der Grafen von Helfenstein, Ulm 1840.

Kurts F.G.G., Denkwürdigkeiten aus der Geschichte der Stadt und Standesherrschaft Wartenberg, Wartenberg 1846.

Müller K.A., Vaterländische Bilder, in eine Geschichte und Beschreibung den alte Burgfesten und Ritterschlösser Preussens, Glogau 1837.

Niesiecki K., Herbarz polski, wyd. J.N. Bobrowicz, t. V, Lipsk 1840.

Pieradzka K., Henryk XI, [w:] Polski słownik biograficzny, t. IX, Wrocław-Warszawa-Kraków 1960-1961, s. 415.

Pol N., Jahrbücher der Stadt Breslau, Bd. II, Breslau 1815; Bd. IV, Breslau 1823.

Schwennicke D., Europäische Stammtafeln. Stammtafeln zur Geschichte der Europäische Staten, Neue Folge, Bd. XII (Schwaben), Marburg 1992; Bd. XVI (Bayern und Franken), Marburg 1995.

Sinapius J., Schleisischer Curiositäten Erste Vorstellung, Darinnen die ansehnilchen Geschlechter Des Schleisischen Adels, Mit Erzehlung Des Ursprungs, der Wappen, Genealogien, der qualificirtesten Cavaliere, der Stamm-Häuser und Güter beschrieben..., Leipzig 1720.

Słownik historyczno-geograficzny województwa poznańskiego w średniowieczu, cz. 1, oprac. S. Chmielewski, K. Górska-Gołaska, J. Luciński, Wrocław 19821987.

Wdowiszewski Z., Genealogia Jagiellonów i Domu Wazów w Polsce, wyd. 2, Kraków 2005.

Urszula Ledóchowska - królewskie pochodzenie, Genealogia Polaków, Dynamiczny Herbarz Rodzin Polskich, http://genealogia.okiem.pl/tron/ledochowska_ urszula.htm (dostęp: 15 XI 2017 r.). 